\title{
Detection of hepatopancreatic parvovirus (HPV) in wild shrimp from India by nested polymerase chain reaction (PCR)
}

\author{
B. Manjanaik, K. R. Umesha, Indrani Karunasagar, Iddya Karunasagar* \\ Department of Fishery Microbiology, University of Agricultural Sciences, College of Fisheries, Mangalore 575002, India
}

\begin{abstract}
The prevalence of hepatopancreatic parvovirus (HPV) in wild penaeid shrimp samples from India was studied by nested polymerase chain reaction (PCR) using primers designed in our laboratory. The virus could be detected in 9 out of 119 samples by non-nested PCR. However, by nested PCR 69 out of 119 samples were positive. The PCR results were confirmed by hybridization with digoxigenin-labelled DNA probe. Shrimp species positive by non-nested PCR included Penaeus monodon, Penaeus indicus and Penaeus semisulcatus and by nested PCR Parapenaeopsis stylifera, Penaeus japonicus, Metapenaeus monoceros, M. affinis, M. elegans, M. dobsoni, M. ensis and Solenocera choprai. This is the first report on the prevalence of HPV in captured wild shrimp from India.
\end{abstract}

KEY WORDS: Hepatopancreatic parvovirus $\cdot$ HPV $\cdot$ Penaeid shrimp $\cdot$ PCR $\cdot$ Captured wild shrimp

\section{INTRODUCTION}

Rapid expansion and intensification of shrimp farming worldwide has led to serious disease outbreaks causing mass mortalities among cultured penaeids. Although different groups of micro-organisms such as bacteria, viruses and parasites can cause diseases in shrimp, the impact of viruses has been the most devastating (Flegel 1997). Viruses that seem to cause little or no disease and seem innocuous in some shrimp species may cause catastrophic disease in others (Lightner \& Redman 1998). Hepatopancreatic parvovirus (HPV) was first reported by Lightner \& Redman (1985) in cultured populations of 4 different penaeid shrimp species from 4 separate culture facilities in China (Penaeus chinensis), Singapore ( $P$. merguiensis), the Philippines (P. monodon) and Kuwait (P. semisulcatus). Currently, HPV is considered a member of the Parvoviridae (Bonami et al. 1995) but its position within the family still remains uncertain. Apparently HPV shows more similarities within the autonomous parvoviruses than with the arthropod infecting parvovirus (Bonami et al. 1995, Pantoja 1999). This virus infects several penaeid species and is widely distributed in many parts of the world including Asia, Africa, Australia and North and South America (Paynter et al. 1985, Colorni et al.1987, Brock \& Lightner 1990, Fulks \& Main 1992, Lightner \& Redman 1992, Lightner 1996). Shrimp affected by HPV show non-specific gross signs, including atrophy of the hepatopancreas, anorexia, poor growth rate, reduced preening activities and a consequent increased tendency for surface and gill fouling by epicommensal organisms (Lightner \& Redman 1985, Chen 1992, Lightner et al. 1992, Sukhumsirichart et al. 1999). In Thailand, HPV was first reported in cultivated P. monodon (HPV-mon) in 1992 (Flegel et al. 1992). The transmission of HPV is believed to be both vertical and horizontal (Lightner \& Redman 1992).

HPV detection traditionally depended upon the histological demonstration of characteristic nuclear inclusion by hematoxylin and eosin (H\&E) staining (Lightner 1996) but more rapid, non-destructive molecular techniques have recently been developed (Mari et al. 
1995, Pantoja \& Lightner 2000, 2001). In India, the presence of HPV along with Monodon baculovirus (MBV) and white spot syndrome virus (WSSV) in hatchery reared postlarvae and heavy mortality of postlarvae has been reported by Manivannan et al. (2002). The prevalence of HPV, MBV and WSSV in $P$. monodon postlarvae in India was reported by Umesha et al. (2003). In this communication we present data on the prevalence of HPV in wild caught shrimp along the southwest coast of India.

\section{MATERIALS AND METHODS}

Sample collection. During the period of study (January 2001 to May 2003) wild shrimp samples were collected from the southwest coast of India at 20 to $60 \mathrm{~m}$ depth by bottom trawling. The samples were preserved in $95 \%$ ethanol on board the vessel.

Extraction of DNA. Samples preserved in 95\% ethanol were rehydrated in sterile distilled water for $1 \mathrm{~h}$. Extraction of viral DNA was carried out by following the method described by Otta et al. (2003) with slight modification. About $100 \mathrm{mg}$ of tissue (hepatopancreas) was taken aseptically in a UV sterilized disposable plastic sachet and homogenized well. To this, $1 \mathrm{ml}$ of guanidine hydrochloride buffer (10 mM Tris $\mathrm{HCl}, \mathrm{pH}$ 8.0, 0.1 M EDTA, pH 8.0, $6 \mathrm{M}$ guanidine hydrochloride and $0.1 \mathrm{M}$ sodium acetate) was added, mixed and allowed to react for $10 \mathrm{~min}$. The homogenate was transferred to a $1.5 \mathrm{ml}$ microfuge tube and

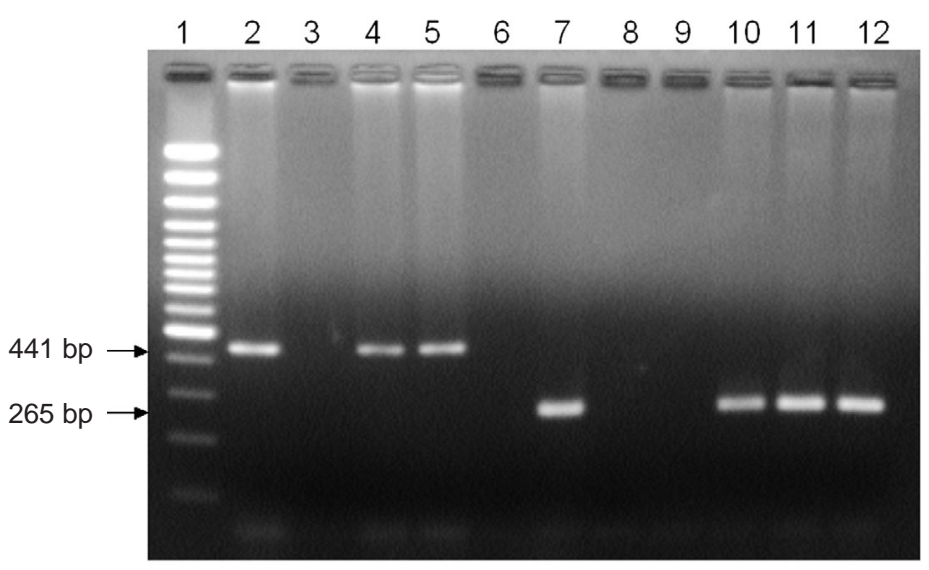

Fig. 1. Sample electrophoresis gel for detection of specific PCR amplicons from hepatopancreatic parvovirus (HPV) by 1-step (Lanes 2-6) and nested (Lanes 7-12) PCR. Lane 1: 100 bp DNA ladder Plus (Gene RulerTM genetix); Lane 2: 1step PCR positive control; Lane 3: negative control; Lanes 4 and 5: HPV detected by 1-step PCR; Lane 6: HPV-negative sample by 1-step PCR; Lane 7: nested PCR positive control; Lane 8: negative control; Lane 9: HPV-negative sample by nested PCR; Lanes 10-12: HPV detected by nested PCR centrifuged at $10000 \times g$ for $5 \mathrm{~min}$. Supernatant $(300 \mu \mathrm{l})$ was transferred to a fresh microfuge tube and $900 \mu \mathrm{l}$ of ice cold absolute ethanol was added. This was mixed a few times by inverting and was subjected to centrifugation at $14000 \times g$ for $10 \mathrm{~min}$. The pellet was washed twice with $95 \%$ ethanol. The DNA pellet was dried in a vacuum drier and dissolved in $100 \mu \mathrm{l}$ sterile distilled water. A portion of this extract was used for PCR assays.

PCR analysis. Two sets of primers were used for the detection of HPV. The PCR program and primer set (H441F and H441R) described by Phromjai et al. (2002) was expected to yield a product of $441 \mathrm{bp}$ (Fig. 1). For nested PCR, primers internal to the $441 \mathrm{bp}$ amplified fragment product were designed. These primers bound to nucleotides 156-176 and 398-420 in the sequence (GenBank Accession No. AF456476) and amplified a 265 bp fragment (Fig. 1). The cycling condition for the nested reaction consisted of an initial delay at $94^{\circ} \mathrm{C}$ for $5 \mathrm{~min}$ followed by 30 cycles at $94^{\circ} \mathrm{C}$ for $30 \mathrm{~s}, 55^{\circ} \mathrm{C}$ for $30 \mathrm{~s}$ and $72^{\circ} \mathrm{C}$ for $30 \mathrm{~s}$ with a final extension at $72^{\circ} \mathrm{C}$ for $5 \mathrm{~min}$. PCR was carried out in a $30 \mu$ reaction mixture consisting of $1 \times$ PCR buffer, 5 pmol of each primer for HPV, $50 \mu \mathrm{M}$ each of dATP, dCTP, dGTP and dTTP, 0.9 units of Taq DNA polymerase and $2 \mu \mathrm{l}$ of DNA extract. Amplification was carried out in a thermocycler (M.J. Research). The amplified PCR products were electrophoresed in $2.0 \%$ agarose gel containing $0.5 \mu \mathrm{g} \mathrm{ml}^{-1}$ ethidium bromide and visualized by UV-transilluminator (Gel doc system, Hero Lab).

Dot blot hybridization. To confirm the PCR product derived from shrimp other than Penaeus monodon, a 196 bp DNA probe was used for dot blot hybridization assays. To generate the probe, DNA extracted from the hepatopancreas of $P$. monodon naturally infected with HPV was amplified using primer pair H441F and H441R. Using the product of this reaction (441 bp), nested PCR was performed using primer pair $\mathrm{HPVF}_{3}$ and $\mathrm{HPVR}_{3}$. The primer $\mathrm{HPVF}_{3}$ bound to nucleotides 192-215 and the primer $\mathrm{HPVR}_{3}$ to nucleotides 365-388 in the sequence with GenBank Accession No. AF 456476. These primers amplified a $196 \mathrm{bp}$ fragment. This product was purified using PCR purification kit (Qiagen) and labeled with digoxigenin 11-dUTP (DIG11-dUTP) by random prime labelling method (Roche, Molecular Biochemicals). The labeled product was used as a probe in dot blot hybridization assays. The PCR products obtained from wild crustaceans (Penaeus semisulcatus, P. indicus, P. japonicus, Parapenaeopsis stylifera, Metapenaeus monoceros, $M$. affinis, M. dobsoni and Solenocera choprai) were denatured for $10 \mathrm{~min}$ in a water bath and snap cooled on ice. Two $\mu l$ of each of the samples were spotted onto a nylon membrane (Nytran, Ny 12 N, Schleicher and 
Schuell) and blotting was done as described by Dyson (1994). The DNA on the nylon membrane was immobilized by a UV crosslinker (UVC 500, Hoefer) and hybridization assays and membrane development were performed according to instructions in the Roche DIG nucleic acid detection kit (Roche Molecular Biochemicals).

Sequencing the PCR product from HPV-infected Penaeus semisulcatus. The PCR product obtained from a wild sample of $P$. semisulcatus using the primer pair $\mathrm{H} 441 \mathrm{~F}$ and H441R was sequenced twice using the same primers both in forward and reverse direction. Sequencing was outsourced to M/s. Bioserve, Hyderabad, India.

\section{RESULTS AND DISCUSSION}

From a total of 119 shrimp samples of various species analyzed for the prevalence of HPV by PCR (Table 1), only 9 were positive by non-nested PCR using primers described by Phromjai et al. (2002). However, an additional 60 samples were positive by nested PCR, bringing the total positive samples to 69/119 (Table 1). Among 72 Penaeus monodon samples analysed, 39 were positive for HPV (6 by non-nested and 39 in nested PCR). Results for other penaeid shrimp species are shown in Table 1.

The nested PCR product obtained with the wild shrimp was confirmed to arise from HPV by dot blot hybridization assays (Fig. 2). Further confirmation was obtained by sequencing the 441 bp PCR fragment obtained from a Penaeus semisulcatus sample. The sequence obtained showed $86 \%$ identity to that of HPV from Thai P. monodon (HPVmon) in the GenBank (AF 456476) (Fig. 3). This was perhaps not surprising since it was previously reported that HPVmon

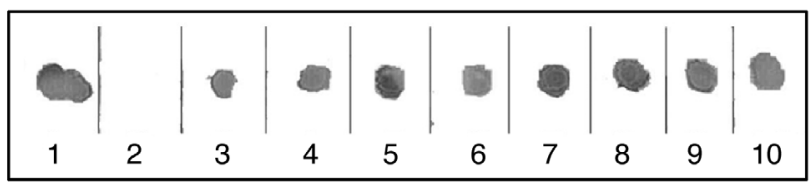

Fig. 2. Example of dot blot hybridisation with digoxigenin (DIG-11-dUTP) probe to confirm identity of hepatopancreatic parvovirus (HPV)-nested PCR amplicons. Lane 1: positive control (nested HPV product); Lane 2: negative control; Lane 3: Penaeus semisulcatus; Lane 4: Penaeus indicus; Lane 5: Parapanaeopsis stylifera; Lane 6: Penaeus japonicus; Lane 7: Metapenaeus monoceros; Lane 8: M. affinis; Lane 9: M. dobsoni; Lane 10: Solenocera choprai

shared $77 \%$ sequence identity to HPV from $P$. chinensis (HPVchin) (Phromjai et al. 2001, Roekring et al. 2002). These constitute sequence variations in HPV detected in different hosts from different geographical locations and it raises the question as to whether these differences are related to host species or regional origin. Our report is the first of HPV in several different shrimp species from the same region and presents the opportunity to answer the question whether the sequence difference we found indicates the occurrence of a regional Indian variant of HPV or a specific HPV variant of $P$. semisulcatus. If any host specific sequences were found, it would open the way for studies on cross-infectivity and virulence.

We have shown that HPV is highly prevalent in wild shrimp varying from 5.0 to $20 \mathrm{~cm}$ in length and 6 to $80 \mathrm{~g}$ in weight (Table 1). Out of all 119 samples tested, $58 \%$ were positive for HPV; this included 72 Penaeus monodon, of which $54 \%$ tested positive. Since captured wild P. monodon are normally used as brooders in Indian hatcheries, it may be useful to screen them for HPV before using them to produce postlarvae for stocking shrimp ponds.

Table 1. Prevalence of hepatopancreatic parvovirus (HPV) in wild shrimp along the southwest coast of India during the period 2001-2003. M: male; F: female

\begin{tabular}{|c|c|c|c|c|c|c|}
\hline Species & $\begin{array}{l}\text { No. of } \\
\text { shrimp }\end{array}$ & $\begin{array}{l}\text { Length } \\
\text { range }(\mathrm{cm})\end{array}$ & $\begin{array}{l}\text { Weight } \\
\text { range }(g)\end{array}$ & $\begin{array}{l}\text { Sex } \\
\text { (n) }\end{array}$ & $\begin{array}{l}\text { No. of positive } \mathrm{H} \\
\text { Non-nested }\end{array}$ & $\begin{array}{l}\text { IPV samples } \\
\text { Nested }\end{array}$ \\
\hline Penaeus monodon & 72 & $15-20$ & $20-80$ & $\mathrm{M}(3) / \mathrm{F}(69)$ & 6 & 33 \\
\hline Penaeus indicus & 3 & $10-12$ & $20-25$ & F (3) & 1 & 2 \\
\hline Penaeus semisulcatus & 4 & $10-15$ & $20-30$ & $\mathrm{~F}(4)$ & 2 & 2 \\
\hline Penaeus japonicus & 6 & $5-6$ & $8-10$ & $\mathrm{~F}(4)$ & & 4 \\
\hline Parapenaeopsis stylifera & 1 & 15 & 20 & $F(1)$ & & 1 \\
\hline Metapenaeus monoceros & 4 & $10-12$ & $10-20$ & $F(1)$ & & 1 \\
\hline Metapenaeus affinis & 5 & $6-8$ & $8-90$ & $F(2)$ & & 2 \\
\hline Metapenaeus elegans & 5 & $6-7$ & $8-9$ & $F(4)$ & & 4 \\
\hline Metapenaeus dobsoni & 10 & $6-8$ & $10-15$ & $F(6)$ & & 6 \\
\hline Metapenaeus ensis & 8 & $4-5$ & $6-7$ & $F(4)$ & & 4 \\
\hline Solenocera choprai & 1 & $5-6$ & 6 & $\mathrm{~F}(1)$ & & 1 \\
\hline Total & 119 & & & & 9 & 60 \\
\hline
\end{tabular}




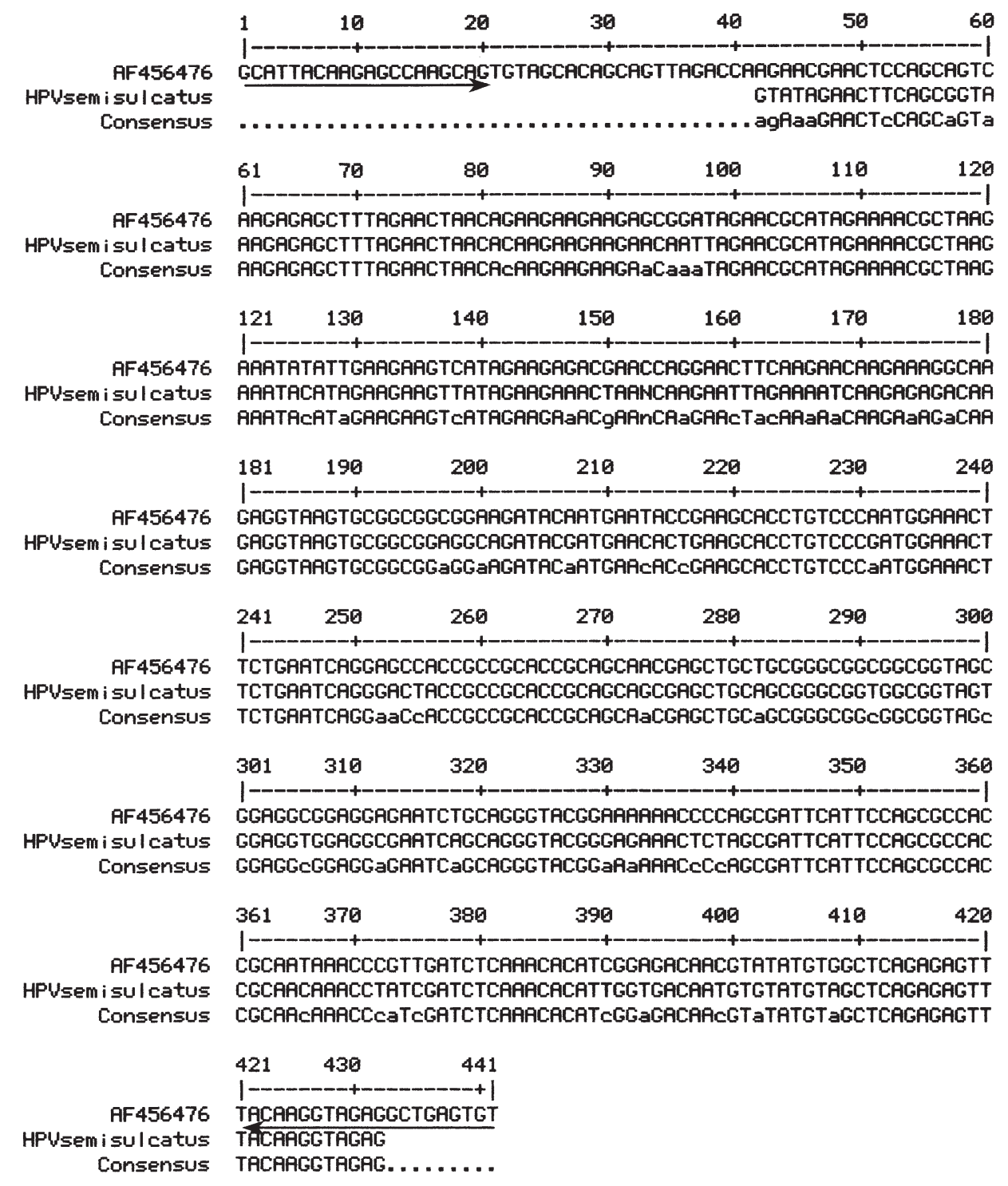

Fig. 3. Alignment of the nucleotide sequence of the hepatopancreatic parvovirus (HPV) PCR amplicon from Penaeus semisulcatus (HPV semisulcatus) with that of P. monodon (HPVmon) AF456476. Arrows indicate primer binding sites

Acknowledgements. The financial support for this work from the Indian Council of Agricultural Research (ICAR) under the National Agricultural Technology Programme (NATP) is gratefully acknowledged.

\section{LITERATURE CITED}

Bonami JR, Mari J, Poulos BT, Lightner DV (1995) Characterization of hepatopancreatic parvolike virus, a second unusual parvovirus pathogenic to penaeid shrimp. J Gen Virol 76:813-817

Brock JA, Lightner DV (1990) Diseases of Crustacea: diseases caused by micro-organisms. In: Kinne O (ed) Diseases of marine animals, Vol III. Biologische Anstalt Helgoland, Hamburg, p 245-349

Chen D (1992) An overview of the diseases situation, diagnostic techniques, treatments and preventives used on shrimp farms in China. In: Fulks W, Main KL (eds) Diseases of cultured penaeid shrimp in Asia and the United states. The Oceanic Institute, Honolulu, HI, p 47-55

Colorni A, Samocha T, Colorni B (1987) Pathogenic viruses introduced into Israeli mariculture systems by imported penaeid shrimp. Bamidgeh 39:21-28

Dyson NJ (1994) Immobilisation of nucleic acids and hybridization analysis. In: Brown TA (ed) Essential molecular biology: a practical approach, Vol II. Oxford University Press, Oxford, p 111-156

Flegel TW (1997) Major viral diseases of the black tiger prawn (Penaeus monodon) in Thailand. In: Invi Y (ed) New approaches to viral diseases of aquatic animals. NRIA International workshop proceedings. National Researcher Institute of Aquaculture, Nansci, p 167-187

Flegel TW, Fegan DF, Vuthikornudomkait S, Kongsom S and 5 others (1992) Occurrence, diagnosis and treatment of shrimp disease in Thailand. In: Fulks W, Main KL (eds) 
Diseases of cultured penaeid shrimp in Asia and the United States. The Oceanic Institute, Honolulu, HI, p 57-112

Fulks W, Main KL (1992) Diseases of cultured penaeid shrimp in Asia and the United States. The Oceanic Institute, Honolulu, HI, p 233-253

Lightner DV (1996) A handbook of shrimp pathology and diagnostic procedures for diseases of cultured penaeid shrimp. World Aquaculture Society, Baton Rouge, LA, p 305

Lightner DV, Redman RM (1985) A parvo-like virus disease of penaeid shrimp. J Invertebr Pathol 45:47-53

Lightner DV, Redman RM (1992) Penaeid virus diseases of the shrimp culture industry of the Americas. In: Fast AW, Lester LJ (eds) Marine shrimp culture: principles and practices. Elsevier, Amsterdam, p 569-588

Lightner DV, Redman RM (1998) Shrimp diseases and current diagnostic methods. Aquaculture 164:201-220

Lightner DV, Bell TA, Redman RM, Mohney LL, Natividad JM, Rukyani A, Poernomo A (1992) A review of some major diseases of economic significance in penaeid prawns/shrimp of the Americas and Indopacific. In: Shariff M, Subasinghe RP, Arthur JR (eds) Diseases in Asian aquaculture. Fish Health Section, Asian Fisheries Society, Manila, p 57-80

Manivannan S, Otta SK, Karunasagar I, Karunasagar I (2002) Multiple viral infection in Penaeus monodon shrimp postlarvae in an Indian hatchery. Dis Aquat Org 48:233-236

Mari J, Lightner DV, Poulos BT, Bonami JR (1995) Partial cloning of the genome of an unusual shrimp parvovirus (HPV): use of gene probes in disease diagnosis. Dis Aquat Org 22:129-134

Otta SK, Karunasagar I, Karunasagar I (2003) Detection of monodon baculovirus and whitespot syndrome virus in apparently healthy Penaeus monodon postlarvae from India by polymerase chain reaction. Aquaculture 220: 59-69

Pantoja CR (1999) Hepatopancreatic parvovirus of penaeid shrimp (HPV): partial cloning and genome characteriza-

Editorial responsibility: Timothy Flegel,

Bangkok, Thailand tion, in situ hybridization at the ultrastructural level, geographic diversity and non-invasive detection. $\mathrm{PhD}$ thesis, University of Arizona, Tucson, AZ

Pantoja CR, Lightner DV (2000) A non-destructive method based on the polymerase chain reaction for detection of hepatopancreatic parvovirus (HPV) of penaeid shrimp. Dis Aquat Org 39:177-182

Pantoja CR, Lightner DV (2001) Detection of hepatopancreatic parvovirus (HPV) of penaeid shrimp by in situ hybridisation at the electron microscope level. Dis Aquat Org 44: 87-96

Paynter JL, Lightner DV, Lester RJG (1985) Prawn virus from juvenile Penaeus esculentus. In: Rothlisberg PC, Hill BJ, Staples DJ (eds) Second Australian National Prawn Seminar. NPS2, Cleveland, QLD, p 61-64

Phromjai, J, Sukhumsirichart W, Pantoja C, Lightner DV, Flegel TW (2001) Different reactions obtained using the same DNA detection reagents for Thai and Korean hepatopancreatic parvovirus (HPV) of penaeid shrimp. Dis Aquat Org 46:153-158

Phromjai J, Boonsaeng V, Withyachumnarnkul B, Flegel TW (2002) Detection of hepatopancreatic parvovirus in Thai shrimp Penaeus monodon by in situ hybridization, dot blot hybridization and PCR amplification. Dis Aquat Org 51: 227-232

Roekring S, Nielson L, Owens L, Pattanakitsakul S, Malasit P, Flegel TW (2002) Comparison of penaeid shrimp and insect parvoviruses suggests that viral transfers may occur between two distantly related arthropod groups. Vir Res 87:79-87

Sukhumsirichart W, Wongteerasupaya C, Boonsaeng V, Panyim S, Sriurairatana S, Withyachumnarnkul B, Flegel TW (1999) Characterization and PCR detection of hepatopancreatic parvovirus (HPV) from Penaeus monodon in Thailand. Dis Aquat Org 38:1-10

Umesha KR, Uma A, Otta SK, Karunasagar I, Karunasagar I (2003) Detection by PCR of hepatopancreatic parvovirus (HPV) and other viruses in hatchery reared Penaeus monodon postlarvae. Dis Aquat Org 57:141-146

Submitted: January 5, 2004; Accepted: October 18, 2004 Proofs received from author(s): February 1, 2005 